\title{
НАВЧАННЯ ЛЕКСИКИ В КУРСІ УКРАЇНСЬКОЇ МОВИ ЯК IHOЗЕМНОї
}

Бакум 3. П., Караман С. О. Навчання лексики в курсі української мови як іноземної.

У статті з'ясовано особливості засвоєння лексики під час навчання української мови як іноземної; розглянуто лінгвістичні, психологічні та лінгводидактичні чинники у збагаченні словникового запасу студентів-іноземців.

Ключові слова: українська мова як іноземна, навчання лексики, лінгвістичні основи, психологічні чинники, семантизація, оносемасіологія.

Бакум 3. П., Караман С. А. Изучение лексики в курсе украинского языка как иностранного.

В статье определены особенности усвоения лексики в процессе изучения украинского языка как иностранного; рассмотрены лингвистические, психологические и лингводидактические факторы в обогащении словарного запаса студентов-иностранцев.

Ключевые слова: украинский язык как иностранный, изучение лексики, лингвистические основы, психологические факторы, семантизация, оносемасиология. language.

Bakum Z. P., Karaman S. O. Teaching the lexicology in the course of the Ukrainian as a foreign

The article deals with the peculiarities of lexicology coherence during the process of studying the Ukrainian as a foreign language; the linguistic, psychological and lingvodidactic criteria of enriching the vocabulary of foreign students are considered as well.

Key words: the Ukrainian as a foreign language, studying the lexicology, linguistic basis, psychological criteria, semantization, onosemasiology.

3-поміж багатьох аспектів іноземної мови, які повинні бути засвоєні в процесі навчання, найважливішим можна вважати лексику, оскільки без запасу слів володіти мовою неможливо. Досвід показує, що засвоєння української лексики викликає у студентів-іноземців неабиякі труднощі, зумовлені обсягом словникового складу, семантикою певної лексичної одиниці, різницею в значеннях слів української та рідної мов.

Усю роботу над лексикою, 3 погляду Я. Коршунової, потрібно підпорядковувати ідеї про те, що студенти мають сприймати слова не як елементи підручника (текстів і вправ), а жити у свідомості самостійно, забезпечуючи змогу виражати власну думку, розуміти висловлене іншими людьми [2, с. 74]. Лише за таких умов можна говорити про оволодіння словом - його значенням, формою (звуковим та зоровим обрисами), здатністю вступати у зв'язки з іншими словами, словотвором, словозміною тощо.

Важливим у практиці засвоєння іншомовної лексики, на думку лінгводидактів (В. Костомаров, А. Щукін, А. Фролкіна), є визначення лексичного мінімуму: активного (слова, якими необхідно послуговуватися в усному мовленні для вираження власних думок) та пасивного, або 
рецептивного (слова, які слід розуміти у процесі читання і слухання іншомовних слів, речень, текстів).

Так, установлено, що активний запас дорослої людини становить приблизно $10 \%$ усього словникового складу ї рідної мови. Активний словниковий запас мовчазного англійця складає 4539 слів, а француза 7500. Для росіянина активний запас може сягати 7500 слів, що і становить біля 10\% словникового складу рідної мови.

Визначаючи лексичний мінімум, яким повинен оволодіти іноземець, який вивчає мову впродовж шести років поза мовним середовищем, зазвичай називають 3000 слів. За підрахунками методистів [3, с. 77 - 78], 3000 спеціально дібраних слів дозволяють зрозуміти 95\% будь-якого тексту. Принагідно зауважимо, що у вітчизняному мовознавстві, на жаль, відсутні лексичні мінімуми сучасної української мови. Тоді як зібрання градуйованих лексичних мінімумів, наприклад, російської мови нараховує сім списків слів від 500 до 3500 найуживаніших слів.

У процесі визначення лексичного мінімуму для початкового етапу за одиницю відбору, або лексичну одиницю, необхідно брати до уваги лексико-семантичний чи лексико-граматичний варіанти слова. Відтак організація методичної роботи над лексикою у процесі навчання української мови як іноземної передбачає врахування лінгвістичних засад, що грунтуються на закономірностях лексикології та семантики. Викладачеві слід керуватися відомостями лінгвістичної науки про слово як основну одиницю мови, що виконує певні функції, головна 3 яких номінативна. Саме у слові виявляється звуковий, семантичний i граматичний аспекти мови, воно є носієм різних лексичних значень, що розкриваються в контексті, залежать від синтаксичної ролі, фразеологічної зв’язності, сполучуваності з іншими словами. А також характеризується сукупністю значень, які неоднаково виявляються в мовленні і слугують для називання різних явищ дійсності: предметів, ознак, дій, кількостей (будинок, чудовий, близько, працювати, n'ять); для позначення різних смислових відношень між словами і реченнями (Прийшов очікуваний день.); для вираження, але не називання різних почуттів (aй, гей); передачі криків тварин чи імітації інших звуків (mьох-тьох).

У низці психологічних передумов навчання лексики чільне місце посідає загальноприйняте твердження про те, що психічні утворення виникають у процесі засвоєння індивідом довкілля на чуттєвому й інтелектуальному рівнях. Результатом інтелектуального відображення дійсності вважають «поняття» і «судження», які відображаються в мовній формі. Оволодіти поняттям означає, по-перше, засвоїти зв’язок між суттєвими ознаками, по-друге, засвоїти зв'язки між поняттями. Розуміння значення слова передбачає усвідомлення взаємозв'язку мислення й мовлення. Значення слова з'ясовується не лише як поєднання мислення й мови, але і як єдність узагальнення та спілкування, комунікації та мислення. 
Під час роботи з іноземними студентами викладачеві не слід лишати поза увагою низку основних психологічних чинників, що характеризують безпосередньо самого студента: мислення (самостійність, швидкість, глибина, рівень продуктивності, співвідношення понятійного й образного компонентів; функціонує поряд 3 мовленням); сприймання (слухове, зорове, дотикове, кінетичне; повнота, точність, швидкість; аналітичний, синтетичний, аналітико-синтетичний тип; навчання грунтується на поєднанні наочності та слова вчителя, конкретних характеристик та узагальнень); пам'ять (короткочасна й довготривала; процеси мимовільного й довільного запам'ятовування; образи, вербальна пам'ять, типи пам'яті - зорова, слухова); увага (мимовільна, довільна, адитивна, візуальна; якості уваги - стійкість, переключення, концентрація, обсяг, розподіл); мотивації (зовнішня, внутрішня; віддалена, близька; пізнавальна, інструментальна, комунікативна).

Для того щоб сформувати в учнів певні лексичні навички у практиці навчання необхідно дотримуватися певних етапів роботи: уведення, семантизація слова, первинне його відтворення; тренування, створення стійких лексичних зв'язків у певних мовленнєвих ситуаціях; етап створення динамічних лексичних мовленнєвих зв'язків.

Отже, робота над словом розпочинається 3 установлення його лексичного значення. Тому одним із найважливіших методів (прийомів) навчання лексики $є$ семантизація - тлумачення лексичного значення, закріпленого в мові за тим чи тим звуковим комплексом.

Прийоми тлумачення грунтуються на об'єктивно наявних у лексиці парадигматичних зв'язках слів. Відтак важливо навчити пояснювати значення слова. Слід розмежовувати методичні поняття «прийом тлумачення» та «джерело тлумачення». М. Баранов акцентував, що не варто вважати прийомом семантизації звернення до тлумачного словника. Важливо, на думку вченого, розмежовувати терміни «спосіб тлумачення» $\mathrm{i}$ «прийом тлумачення» [1, с. 37].

Пояснення значення слова може відбуватися двояко: від плану змісту до плану вираження, від поняття до слова - оносемасіологічний спосіб тлумачення; і навпаки - від плану вираження до плану змісту, від слова 3 відомим значенням до значення нового слова - семантичний спосіб.

Пропонуємо виокремлювати два шляхи тлумачення значення слова оносемасіологічний та семантичний (див. таблицю 1).

Важливою ланкою в системі роботи над лексикою $є$ вправи, їх послідовність:

1. Пропедевтичні, або підготовчі вправи. Мета таких вправ забезпечити первинне сприймання слова, а саме - дати семантичне визначення слову, зіставити його з екстралінгвальною реалією; пояснити особливості орфоепії та орфографії. 
Методи і прийоми тлумачення слів

\begin{tabular}{|c|c|l|}
\hline \multicolumn{1}{|c|}{ Метод } & \multicolumn{1}{|c|}{ Прийом } & \multicolumn{1}{|c|}{ Приклад } \\
\hline Оносемасіологічний & Наочний & Показ предмета, зображення \\
\hline Оносемасіологічний & Контекстуальний & 3’ясування значення слова з контексту \\
\hline Семантичний & Синонімічний & Розумний-кмітливий, здогадливий \\
\hline Семантичний & Антонімічний & $\begin{array}{l}\text { Щирість - відсутність } \\
\text { неправди, обману }\end{array}$ \\
\hline Семантичний & Логічний (родове \\
поняття) & $\begin{array}{l}\text { Сором'язливість - риса характеру } \\
\text { несмілої людини }\end{array}$ \\
\hline Семантичний & $\begin{array}{l}\text { Описовий (використання } \\
\text { описового звороту) }\end{array}$ & $\begin{array}{l}\text { Сором’язливість - якість характеру } \\
\text { людини, якій важко вчинити будь- } \\
\text { який поступок }\end{array}$ \\
\hline Семантичний & $\begin{array}{l}\text { Словотвірний і етимологічний } \\
\text { (використання споріднених } \\
\text { слів та етимології слова) }\end{array}$ & $\begin{array}{l}\text { Щирість - риса людини, яка завжди } \\
\text { говорить правду; } \\
\text { Азбука - порядок літер, який колись } \\
\text { починався з букв Аз і Буки }\end{array}$ \\
\hline
\end{tabular}

2. Ілюстративні вправи. Мають на меті демонстрування учням зразків уживання слова. Вставляючи нове слово в речення, повторюючи вголос або записуючи зразки словосполучень, слів, дитина засвоює значення слова в контексті, оволодіває синтагматичними зв'язками певної лексичної одиниці, одночасно осягає граматику слова. На цьому етапі $\epsilon$ ефективною робота зі словником, використання невеликих за обсягом текстів.

3. Основні, або вправи для закріплення. Унаслідок виконання цих вправ студенти оволодівають парадигматичними зв'язками слів: у них формується вміння добирати до слова синоніми, антоніми, давати логічне визначення; школярі засвоюють структурно-семантичні зв’язки слів.

\section{4. Повторювально-узагальнювальні вправи забезпечують} засвоєння багатозначності слова; дають змогу не лише закріпити слово в пасивному словнику, а й увести в активний обіг. До вправ такого зразка належать, наприклад, добір студентами власних прикладів, що ілюструють уживання слова; створення власних висловлювань; добір слів за темою, об'єднання слів у лексико-семантичні групи.

5. Творчі завдання передбачають послуговування мовним матеріалом у зв'язному мовленні.

Окрім названих вправ доцільно використовувати ще й такі:

- знаходження певної одиниці в контексті;

- з'ясування ролі лексичного явища в аналізованому тексті;

- добирання прикладів, що ілюструють лексичне значення;

- групування лексичних явищ за певними ознаками;

- конструювання мовних одиниць із певним лексичним явищем;

- робота зі словниками. 
Важлива роль належить лексичному аналізові тексту, що здійснюється у трьох аспектах: 1) сутність значення слова; 2) співвідношення слова і поняття.

Робота щодо попередження лексичних помилок передбачає усвідомлення причин і механізмів їх появи. 3-поміж найпоширеніших лексичних помилок варто звертати увагу на такі види:

1) уживання слова в неправильному значенні;

2) сплутування слів-синонімів;

3) сплутування слів-паронімів;

4) сплутування антонімів;

5) сплутування асоціативно близьких слів;

6) тавтологія, невиправданий повтор;

7) порушення лексичної сполучуваності;

8) невиправдане трансформування фразеологізмів або їх уживання в неправильному значенні.

Отже, основна мета роботи над засвоєнням лексики полягає у формуванні лексичних навичок студентів, усвідомлення викладачем лінгвістичних, психологічних та лінгводидактичних засад навчання мови.

\section{Література}

1. Баранов М. Т. Методика лексики и фразеологии на уроках русского языка / М. Т. Баранов. - М. : Просвещение, 1988. - 217 с.

2. Коршунова Я. Б. Обучение лексике : пособие по методике преподавания русского языка как иностранного / Я. Б. Коршунова. - М. : Просвещение, 1984. - 147 с.

3. Фролкина А. В. Работа над лексикой // Методика преподавания русского языка как иностранного на начальном этапе. - М. : Просвещение, 1989. - [3-е изд.]. - 285 с. 